\title{
THE EFFECTS OF CLINOPTILOLITE ADMINISTRATION ON THE APPETITE, THE CONSISTENCY OF FAECES AND THE HISTOLOGY OF THE SMALL INTESTINE IN GROWING PIGS
}

\author{
Novotný, J. ${ }^{1}$, Reichel, P. ${ }^{1}$, Bárdová, K. ${ }^{1}$, Kyzeková, P. ${ }^{1}$, Almášiová, V. ${ }^{2}$ \\ ${ }^{1}$ Clinic for Swine \\ ${ }^{2}$ Department of Histology and Embryology \\ University of Veterinary Medicine and Pharmacy, Komenského 73, 04181 Košice \\ Slovakia
}

jaroslav.novotny@uvlf.sk

\section{ABSTRACT}

Clinoptilolite $(\mathrm{Cp})$ is the most common and suitable natural zeolite type for many commercial and industrial applications. Recent studies have also shown a high potential of clinoptilolite in various medical applications. The aim of our study was to evaluate the effect of longterm peroral administration of clinoptilolite on appetites, the consistency of faeces, and the histopathology of the intestines of growing pigs. Fourteen Landrace $x$ Large White crossbred pigs of both genders, a few days after weaning $(12.95 \mathrm{~kg} \mathrm{~b}$. w.), were divided into two equal groups. The control group was fed with a basal feed mixture, and the experimental group with a feed mixture supplemented with $2 \%$ of natural zeolite (the commercial preparation "ZeoFeed"). The appetite, clinical state and consistency of the faeces were assessed every day. The blood samples were collected on days 0,21 , and 42 of the experiment. Histological examinations of the intestines from the control and experimental animals were carried out at the end of the experiments. The supplementation of $2 \% \mathrm{Cp}$ did not affect neither the appetite nor the clinical state of the pigs. The faecal consistency score in the experimental animals was $18.82 \%$ lower than that of the control piglets. The histopathological evaluations showed protective evidence of the $\mathrm{Cp}$ on the intestinal tract wall in the duodenum and jejunum.

Key words: appetite; faeces; growing pigs; zeolite clinoptilolite

\section{INTRODUCTION}

Clinoptilolite is a microporous natural form of zeolite which has a three dimensional dense network of aluminosilicates, characterized by plentiful internal spaces in the form of channels and cavities with an internal negative charge, which provides its specific absorptive and ion-exchanging properties. The cavities may entrap molecules of different solids, liquids or gaseous substances, for example: methane, carbon dioxide, ammonia, steam, etc. [22]. Due to its structure and properties, this natural inert and nontoxic material can be used as a slow-release carrier of fer- 
tilizers, as well as other agrochemical, pharmaceutical and biochemical active compounds including disinfectants. Natural zeolite can also be used to improve the physical properties of soils and to treat contaminated soils [17].

The specific physicochemical properties of clinoptilolite are the prerequisite for its use also in animals [22]. In veterinary medicine, the supplementation of $\mathrm{Cp}$ can be used to protect against ammonia toxicity by binding ammonia in vivo $[10,20]$. Clinoptilolite also has the ability to bind some polar mycotoxins, especially aflatoxins [18, 19, 24]. Moreover, it provides some protection against zearalenone [16]. Cp is also capable to act as: an antioxidant, haemostatic, anti-diarrheic, growth-promoting and immunostimulating agent $[3,4,25,30]$. Zeolites improve the ability to resist some diseases, promote some positive effects as an antioxidant and may have antiviral attributes [12].

Despite extensive use of clinoptilolite, the mechanisms underlying the action of $\mathrm{Cp}$ in its natural or modified forms are still unclear [7]. For instance, further research is needed to elucidate the direct effects of zeolite on the morphology and physiology of the small intestine [29].

The aim of this study was to evaluate the effects of infeed inclusion of a natural zeolite (clinoptilolite) on the appetite, consistency of faeces, and the histological structure of the intestines in growing pigs.

\section{MATERIALS AND METHODS}

\section{Animals}

Fourteen clinically healthy pigs (crossbreed Large White $\times$ Landrace) of the same age (36 days), with an average body weight of $12.95 \mathrm{~kg}$ were randomly divided into two equal groups: experimental and control.

\section{Experimental design}

In the experiments lasting 6 weeks, the control pigs were fed with a commercially prepared dry mixture recommended for this category of animals (OŠ-02, Polnonákup Šariš a. s., Prešov, Slovakia). The experimental pigs were fed the same dry feed mixture supplemented with $2 \%$ of a commercially preparation "ZeoFeed" (natural zeolitetype clinoptilolite) prepared by the company Zeocem a.s. (Bystré, Slovakia). Its mineralogical and chemical composition is shown in Table 1. Feed and water were available ad libitum. The animals were housed under standard hous- ing indoor conditions on a solid floor at the Clinic for swine of the UVMP in Košice. The appetite, clinical state and consistency of faeces were evaluated each day after morning feeding. Venous blood was sampled from the ophthalmic sinus on days 021 , and 42 of the experiments.

\section{Diagnostic testing}

The concentrations of leukocytes (Lc) were measured using an animal blood counter (abc TM Vet.).

\section{Assessment of the consistency of faeces}

A five-point scale was implemented: 1-Solid; 2-Paste; 3-Thin; 4-Watery; 5-Admixtures (blood, mucus).

\section{Histological examinations}

After termination of the experiments the animals were euthanized. The intestinal tissue samples were flushed with a physiological saline, fixed in $10 \%$ formalin, dehydrated in ethanol solutions with increasing concentration, and embedded in paraffin. The $5 \mu \mathrm{m}$ thick sections were prepared, stained with haematoxylin and eosin and examined under a light microscope Zeiss Axio Lab A1, and documented with a camera Axio Cam ERc 5.

\section{Statistical processing of results}

The statistical processing of the results was performed by assessment of means (x) and standard deviations (SD) in both groups of pigs. The significance (P) of differences in the means of corresponding variables were evaluated by the Student's t-tests.

\section{RESULTS}

The appetites of the animals during the entire period of the experiments were excellent without any apparent changes. It was determined that all of the pigs had their body temperature, pulse and respiratory rate in the normal physiological ranges $\left(39.3 \pm 0.3{ }^{\circ} \mathrm{C}\right.$; respiration $25-40$; and pulse $80-100)$. A comparison of the concentration of white blood cells (Table 2) with the reference range $\left(11.0-18.0{\left.\mathrm{G} . \mathrm{l}^{-1}\right)}^{-}\right.$ [28] indicated a leucocytosis in the control group at the 1st and 2 nd collection, while in the experimental group a leucocytosis was seen only at the 2 nd collection.

The most liquid faeces were observed up to five days after the beginning of the experiments in the control group. 
On the other hand, the faecal consistency score was relative stabile throughout the experiment in the Cp treated group.

The histopathological changes were detected in the duodenum and jejunum. The mucosa and submucosa of these segments of the small intestine of the both control and experimental animals revealed apparent inflammatory infiltrations. The infiltrates occurred in the lamina propria mucosae, tela submucosa and in the epithelial lin-

Table 1. Mineral and chemical composition of ZeoFeed clinoptilolite

\begin{tabular}{cc}
\hline Parameter & Content \\
\hline $\begin{array}{c}\text { Clinoptilolite } \\
\text { of sediment origin } \\
\text { Clay minerals } \\
\text { Particle size }\end{array}$ & Not less than $80 \%$ \\
Loss on drying & $0.01-0.2 \mathrm{~mm}$ \\
$\mathrm{SiO}_{2}$ & $\leq 6 \%$ \\
$\mathrm{Al}_{2} \mathrm{O}_{3}$ & $62-73 \%$ \\
$\mathrm{Si}_{\mathrm{Al}}$ ratio & $11-14 \%$ \\
$\mathrm{CaO}^{2}$ & $4.8-5.40$ \\
$\mathrm{Na}_{2} \mathrm{O}$ & $2-5.50 \%$ \\
$\mathrm{Fe}_{2} \mathrm{O}_{3}$ & $0.2-1.5 \%$ \\
$\mathrm{~K}_{2} \mathrm{O}$ & $0.7-2.3 \%$ \\
$\mathrm{MgO}^{\mathrm{TiO}}$ & $2.2-3.4 \%$ \\
\hline
\end{tabular}

ing. They consisted mainly of lymphocytes, but also some neutrophils, macrophages, and plasma cells at different locations were seen. The mucosa of the duodenum and jejunum in the control animals revealed diffuse degenerative histopathological changes. The intestinal villi were reduced in size, mostly disintegrated and completely devoid of the epithelial covering. The general morphology of the Lieberkühn crypts as well as other deeper layers of the intestinal wall were not affected. On the contrary, in the experimental group, the intestinal villi were comparatively larger, mostly regular in shape, and covered by the continuous epithelium (Fig. 2).

\section{DISCUSSION}

The supplementation of $2 \% \mathrm{Cp}$ during forty-two days of experiment did not influence the appetite or the clinical state of the pigs. It is in accordance with the studies by Prvulović et al. [15] and Papaioannou et al., [12] where Cp ingestion was well tolerated by pigs. Several

Table 2. Concentration of white blood cells in G. $\mathrm{I}^{-1}(x \pm$ SD)

\begin{tabular}{llll}
\hline Sampling Day & $\mathbf{0}$ & 1st & 2nd \\
\hline Experimental group & $16.83 \pm 3.02$ & $16.95 \pm 0.82$ & $20.65 \pm 2.13$ \\
Control group & $16.28 \pm 4.33$ & $22.45 \pm 4.01$ & $23.13 \pm 4.81$ \\
\hline
\end{tabular}

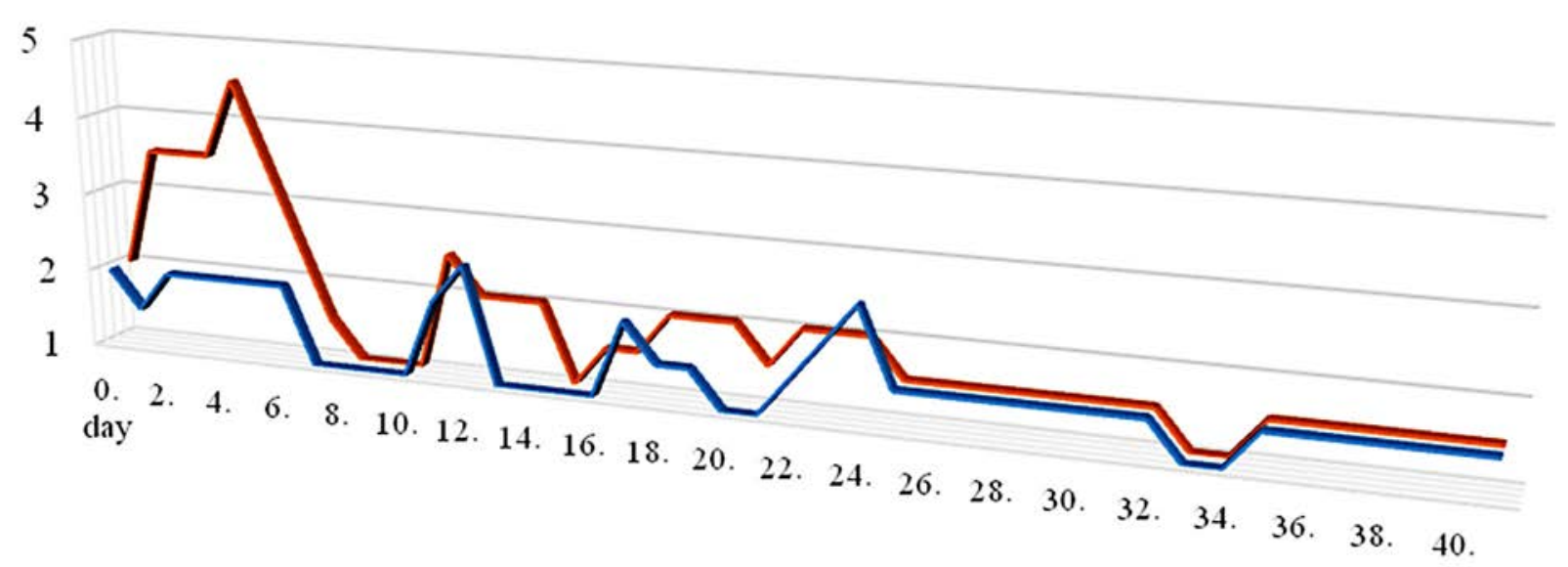

axperimental EControl

Fig. 1. Faecal consistency score 

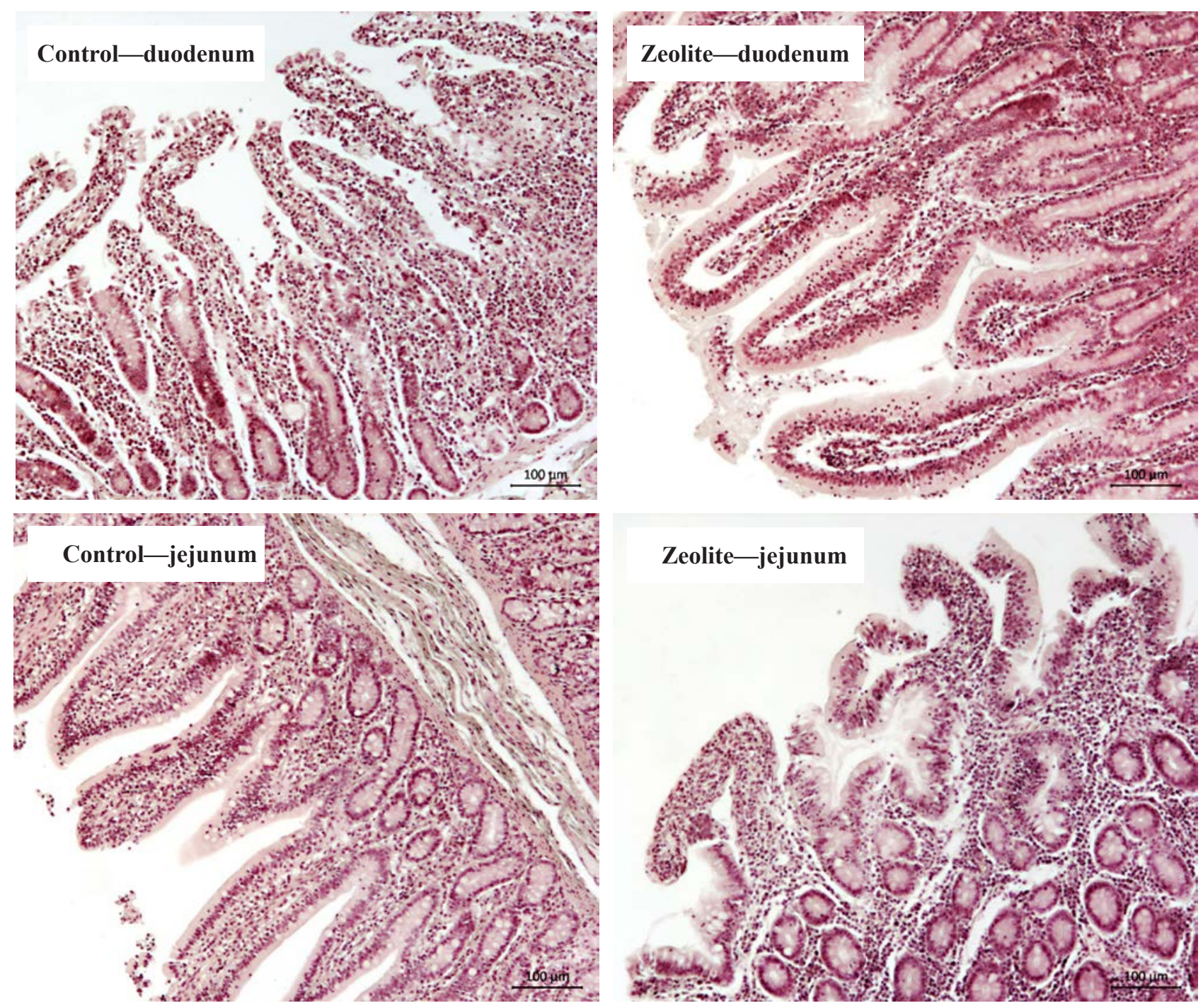

Fig. 2. Representative microphotographs showing histopathological changes and inflammatory infiltrations of duodenum and jejunum, haematoxylin-eosin. Magn. $\times 100$

toxicological studies as well as haematological, biochemical and histopathological analyses dealing with natural $\mathrm{Cp}$ proved that this compound is non-toxic and safe for use in human and veterinary medicine $[1,15,21,26]$.

The supplementation of $\mathrm{Cp}$ to the basal diets in our experiment decreased the faecal consistency score. It was by $18.82 \%$ lower (more solid faeces) than in the non-treated control piglets. In a similar five-week study [25] of Cp supplementation, there was recorded about $12.96 \%$ decrease in diarrhoea severity score compared to non-treated piglets. The action of natural zeolite in the digestive system is interpreted as prolongation of the retention time of digesta in the gut of pigs [11]. Similarly, P r v u lovi ć et al. [15] described a longer retention time of the digesta in the gut of pigs, slower passage of ingesta through the gastrointestinal tract and increased microbial activity in the small intestine leading to better utilization of nutrients. Also, the water adsorption properties of the natural zeolites resulted in drier and more compact faeces [13].

Pigs in the early phases of growth, up to around $25 \mathrm{~kg}$ live weight, tend to be less tolerant to feed ingredients of low digestibility and thus in this age group, the feed specification is more critical. Profound physiological changes occur as a result of abrupt weaning, notably a change of high $\mathrm{pH}$ to low $\mathrm{pH}$ in the stomach; a change in the profile of digestive enzymes, particularly with respect to dealing with starch. At the same time, stunting of the intestinal villi reduces the absorptive capacity in the ileum. These changes render the gut more susceptible to pathogens [6]. $\mathrm{P}$ a p a i o a n ou et al., [13] found that Cp zeolite can adsorb dietary substances linked to intestinal hypersensitivity and restore digestive enzyme activity. 
The incidences of diarrhoea have been reported as $32 \%$ [2] and $39 \%$ [5] for the period from weaning up to 14 days post-weaning. $\mathrm{Nabuurs}$ [8] reported an incidence of diarrhoea of $40 \%$ during the first, $69 \%$ during the second and $50 \%$ during the 3 rd post-weaning week of piglets reared under commercial conditions. It would appear that the piglets in this study showed extensive diarrhoea, but it should be noted that the faeces score in this study was not equivalent to overt diarrhoea [27]. In our experiments, the most liquid faeces-thin to watery consistency-was observed up to five days after the beginning of the experiment (day 7 post-weaning) in the control group. On the contrary, denser, pasty consistency in the experimental group was observed in parallel. The consistency of faeces did not stabilise up to day 25 of the experiment (day 27 post-weaning).

The published data provides evidence that piglets with more liquid faeces have shorter intestinal villi, which may reflect that shorter villi result in decreased faeces consistency [27]. N a b u u r s et al. [9] showed on a herd level that the mean villus height in diarrhoeic herds was relatively lower than in the specific pathogen-free (SPF) herds. The villus height and crypt depth may influence the pathogenesis of post-weaning diarrhoea, as suggested by $\mathrm{N}$ a b u u r s et al. [9], through the absorptive and secretive properties of small intestine enterocytes [14]. Our histological examination showed more severe changes in the duodenum and jejunum of the control group. These changes could be associated with leucocytosis recorded on days 21 and 42 of the experiment. On the other hand, the experimental group (leucocytosis on day 42 of the experiment) had comparatively larger intestinal villi that were regular in shape and were covered by continuous epithelium. These morphological results in the small intestine after supplementation of $\mathrm{Cp}$ are in accordance with the studies of $\mathrm{S} \mathrm{ubram}$ a $\mathrm{niam}$ and $\mathrm{Kim}$ [23], and also W a w r z y n i a k [29] where dietary zeolite caused morphological changes in the intestinal villi and improved intestinal function in pigs and in female broilers. An increase in the villus height enhances the surface area for nutrient absorption thus it increases nutrient digestibility [23].

The most important factors for clinoptilolite performance are the concentration, purity and type of supplemented clinoptilolite as well as the growth phase of animals [15].

Our experiment allowed us to conclude that the dietary addition of $2 \%$ of natural zeolite clinoptilolite affected pos- itively the faecal consistency score and histological findings in duodenum and jejunum of growing pigs.

\section{REFERENCES}

1. Alexopoulos, C., Papaioannou, D. S., Fortomaris, P., Kyriakis, C. S., Tserveni-Goussi, A., Yannakopoulos, A., Kyriakis, S. C., 2007: Experimental study on the effect of in-feed administration of a clinoptilolite-rich tuff on certain biochemical and haematological parameters of growing and fattening pigs. Livest. Sci., 111, 230-241. DOI: 10.1016/j. livsci.2007.01.152.

2. Ball, R. O., Aherne, F. X., 1982: Effect of diet complexity and feed restriction on the incidence and severity of diarrhoea in early-weaned pigs. Can. J. Anim. Sci., 62, 907-913.

3. Colella, C., 2011: A critical reconsideration of biomedical and veterinary applications of natural zeolites. Clay Miner., 46, 295-309. DOI: 10.1180/claymin.2011.046.2.295.

4. Ghasemi, Z., Sourinejad, I., Kazemian, H., Rohani, S., 2016: Application of zeolites in aquaculture industry: a review. Rev. Aquaculture, 10, 75-95. DOI: 10.1111/raq.12148.

5. Hampson, D. J., 1986: Influence of creep feeding and dietary intake after weaning on malabsorption and occurrence of diarrhoea in newly weaned pig. Research in Veterinary Science, 41, 1, 63-69.

6. Mackinnon, J. D., 2015: Differential Diagnosis of Post-weaning Diarrhoea in Pigs. https://www.pig333.com/articles/differential-diagnosis-of-post-weaning-diarrhoea-in-pigs_10484/.

7. Mastinu, A., Kumar, A., Maccarinelli, G., Bonini, S. A., Premoli, M., Aria, F., et al., 2019: Zeolite clinoptilolite: Therapeutic virtues of an ancient mineral. Molecules, 24, 8 . DOI: $10.3390 /$ molecules24081517.

8. Nabuurs, M. J. A., 1991: Etiologic and Pathogenic Studies on Postweaning Diarrhoea. PhD. Thesis, State University of Utrecht, Centraal Diergeneeskundig Instituut. Lelystad, the Netherlands, 131 pp.

9. Nabuurs, M. J. A., Hoogendoorn, A., Van Der Molen, E. J., Osta, A. L. M., 1993: Villus height and crypt depth in weaned and unweaned pigs, reared under various circumstances in the Netherlands. Res. Vet. Sci., 55, 78-84.

10. Nakaue, H. S., Koelliker, J. K., 1981: Studies with clinoptilolite in poultry. I. Effect of feeding varying levels of clinoptilolite (zeolite) to dwarf Single Comb White Leghorn pullets and ammonia production. Poult. Sci., 60, 944-949. DOI: 10.3382/ ps.0600944. 
11. Ouhida, I., Pérez, J. F., Piedrafita, J., Gasa, J., 2000: The effects of sepiolite in broiler chicken diets of high, medium and low viscosity. Productive performance and nutritive value. Anim. Feed Sci. Technol., 85, 183-194. DOI: 10.1016/S03778401(00)00148-6

12. Papaioannou, D. S., Kyriakis, C. S., Alexopoulos, C., Tzika, E. D., Polizopoulou, Z. S., Kyriakis, S. C., 2004: A field study on the effect of the dietary use of a clinoptilolite-rich tuff, alone or in combination with certain antimicrobials, on the health status and performance of weaned, growing and finishing pigs. Res. Vet. Sci., 76, 1, 19-29. DOI: 10.1016/j. rvsc.2003.08.006

13. Papaioannou, D., Katsoulos, P. D., Panousis, N., Karatzias, H., 2005: The role of natural and synthetic zeolites as feed additives on the prevention and/or the treatment of certain farm animal diseases: A review. Microporous Mesoporous Mater., 84, 161-170. DOI: 10.1016/j.micromeso.2005.05.030.

14. Powell, D. W., 1987: Intestinal water and electrolyte transport. In Johnson, J. R. (Ed.): Physiology of the Gastrointestinal Tract, 2nd edn., Raven Press, New York., 1267-1305.

15. Prvulović, D., Jovanović-Galović, A., Stanić, B., Popović1, M., Grubor-Lajšić, G., 2007: Effects of a clinoptilolite supplement in pig diets on performance and serum parameters. Czech J. Anim. Sci., 52, 6, 159-164. DOI: 10.17221/2317-CJAS.

16. Ramos, A. J., Fink-Gremmels, J., Hernandez, E., 1996: Prevention of toxic effects of mycotoxins by means of nonnutritive adsorbent compounds. J. Food Prot., 59, 631-641.

17. Reháková, M., Čuvanová, S., Dzivák, M., Rimár, J., Gavalová, Z., 2004: Agricultural and agrochemical uses of natural zeolite of the clinoptilolite type. Curr. Opin. Solid State Mater. Sci., 8, 6, 397-404. DOI:10.1016/j.cossms.2005.04.004.

18. Sabater-Vilar, M., Malekinejad, H., Selman, M. H. J., Van Der Doelen, M. A. M., Johanna FinkGremmels, J., 2007: In vitro assessment of adsorbents aiming to prevent deoxynivalenol and zearalenone mycotoxicoses. Mycopathologia, 163, 81-90. DOI: 10.1007/s11046-007-0093-6.

19. Sabet, F. A., Libre, N. A., Shekarchi, M., 2013: Mechanical and durability properties of self-consolidating high performance concrete incorporating natural zeolite, silica fume and fly ash. Construct. Building Mat., 44, 175-84. DOI: 10.1016/j. conbuildmat.2013.02.069.

20. Shurson, G. C., Ku, P. K., Miller, E. R., Yokoyama, M. T., 1984: Effects of zeolite A or clinoptilolite in diets of growing swine. J. Anim. Sci., 59, 1536-1545.

21. Šperanda, M., Liker, B., Šperanda, T., Šerić, V., Antunović, Z., Grabarević, Ž., et al., 2006: Haematological and biochem- ical parameters of weaned piglets fed on fodder mixture contaminated by zearalenone with addition of clinoptilolite. Acta Vet. (Beograd), 56, 121-136. DOI: 10.2298/AVB0603121S.

22. Straková, E., Suchý, P., Herzig, I., Šerman, V., Mas, N., 2008: The long-term administration of a clinoptilolite-supplemented feed to layers and its effect on performance, haematological parameters and metabolic profile. Czech J. Anim. Sci., 53, 5, 212-218. DOI: 10.17221/311-CJAS

23. Subramaniam, M. D., Kim, I. H., 2015: Clays as dietary supplements for swine: A review. J. Anim. Sci. Biotechnol.. 6, 1, 38. DOI: 10.1186/s40104-015-0037-9.

24. Thieu, N. Q., Ogle, B., Pettersson, H., 2008: Efficacy of bentonite clay in ameliorating aflatoxicosis in piglets fed aflatoxin contaminated diets. Trop. Anim. Health Prod., 40, 649-656. DOI:10.1007/s11250-008-9144-3.

25. Valpotic, H., Terzic, S., Vince, S., Samardzija, M., Turk, R., Lackovic, G., et al., 2016: In-feed supplementation of a clinoptilolite favorably modulates intestinal and systemic immunity and some production parameters in weaned pigs. Vet. Med., 61, 317-327. DOI: 10.17221/175/2015-VETMED.

26. Valpotić, H., Barić-Rafaj, R., Mrljak, V., Grabarević, Ž., Samardžija, M., Šperanda, M., et al., 2017: Influence of dietary mannan oligosaccharide and clinoptilolite on hematological, biochemical and gut histological parameters in weaned pigs. Period. Biol., 119, 63-73. DOI: 10.18054/ pb.v119i1.4407.

27. Vente-Spreeuwenberg, M. A. M., Verdonk, J. M. A. J., Beynen, A. C., Verstegen M. W. A., 2003: Interrelationships between gut morphology and faeces consistency in newly weaned piglets. J. Anim. Sci., 77, 85-94.

28. Vrzgula, L., Sokol, J., 1990: Interpretation of haematological profile (in Slovak). In Vrzgula, L., et al. (Ed.): Disorders of Metabolism of Domestic Animals and their Prevention, 470472.

29. Wawrzyniak, A., Kapica, M., Stępień-Pyśniak, D., Szewerniak, R., Olejarska, A., Jarosz, Ł., 2017: Effect of feeding transcarpathian zeolite on gastrointestinal morphology and function in broiler chickens. Brazilian Journal of Poultry Science, 19, 4, 737-746.

30. Wu, Q. J., Wang, L. C., Zhou, Y. M., Zhang, J. F., Wang, T., 2013: Effects of clinoptilolite and modified clinoptilolite on the growth performance, intestinal microflora, and gut parameters of broilers. Poult. Sci., 92, 684-692.

Received June 26, 2019

Accepted August 20, 2019 